\title{
Preparation and characterization of oxidized Multi-walled Carbon Nanotubes-Immobilized Aspergillus sp. Laccase Hybrid Materials
}

\author{
A.A. Haroun ${ }^{1,}{ }^{*}$, R.A. Masoud ${ }^{1}$ \\ ${ }^{1}$ Chemical Industries Research Division, National Research Centre, 12622 Dokki, Giza, Egypt \\ ${ }^{*}$ Corresponding authors email: haroun682000@yahoo.com \\ DOI: https://doi.org/10.34256/irimt21410 \\ Received: 10-06-2021, Accepted: 08-07-2021, Published: 12-07-2021
}

Abstract: This work deals with preparation and characterization of immobilized laccase (Aspergillus sp.) over oxidized multi-walled carbon nanotubes (ox-MWCNTs) via simple mixing technique. The resulting materials were characterized by Fourier transform infrared spectroscopy (FTIR), thermogravimetric analysis (TGA), transmission electron microscope (TEM) and particle size distribution analysis using dynamic light scattering technique (DLS). The results showed that the TEM images exhibited more separate individual carbon bundles with particle size around of $396 \mathrm{~nm}$ after enzyme immobilization rather than the spaghetti-like tubes with size about $180 \mathrm{~nm}$ in the case of ox-MWCNTs. Also, the lowering in the zeta potential negative value $(-5 \mathrm{mv})$ proved that the free carboxyl groups at ox-MWCNT surface were decreased after enzyme immobilization. Moreover, the thermal stability was decreased after enzyme immobilization using TGA. These results confirmed that the laccase could be reacted at the side walls of the ox-MWCNTs without structure damage. The biocatalytic effect of the immobilized laccase was investigated after its incubation with silver nitrate solution for 1 and $24 \mathrm{~h}$. It can be concluded that the biocatalytic efficiency of the immobilized laccase could be enhanced after its incubation with silver nitrate solution for $24 \mathrm{~h}$ at room temperature relative to the free form. On the other hand, the enzyme stability was improved after immobilization up to $50^{\circ} \mathrm{C}$ and at $\mathrm{pH} 3.0$, while no remarkable differences on the activity values were observed for immobilized and free laccases at acidic $\mathrm{pH}$ range (4-6).

Keywords: Multi-walled carbon nanotubes, Functionalization, Biocatalysts, Enzyme immobilization, Laccase enzyme, Enzyme stability.

\section{Introduction}

Carbon nanotubes (CNTs) have been considered as an ideal nano-carrier in the field of nanomedicine, which is an applicative field that uses concepts of nanotechnology, biology and medicine. The various applications of these include: controlled drug delivery; targeted delivery of drug molecules to a specific site, in addition to delivery of bionanotechnology products; as an additive to improve the solubility of the slight water-soluble drugs; hormone and enzyme [1-4]. Using of CNTs as carriers for enzyme immobilization is recently reported for several applications [5-10]. Functionalization of CNTs with organic, polymeric and biological molecules can provide biocompatible nanotube composites with specific groups on their surface. Furthermore, Haroun et al. [10-18] reported that novel functionalized MWCNTs-based nanocomposites could be prepared for several applications. Besides, Aspergillus flavus, levansucrase and L-asparaginase enzymes were successfully immobilized onto oxidized MWCNTs [19-
22]. Enzyme immobilization is advantageous due to enzyme recovery from the product can be easier, also enzyme reuse and process scaling up. Moreover, immobilized enzymes sometimes have higher activity, stability, selectivity and resistance to inhibitors [23-25]. On the other hand, the free enzymes sever from many disadvantageous such as their deactivation under drastic conditions [26]. Consequently, the enzymes immobilization on CNTs is considered an effective strategy for improving the long-term stability and reusability [27-42]. Generally, many techniques for enzyme loading on carriers including adsorption, covalent bonding, entrapment or encapsulation, have been previously reported [43]. However, during the catalytic reaction, the easily enzyme leaching may be limited its utilization at industrial scale. Thus, the interaction between the enzyme and the carrier is gained more attention for development of highly active and stable biocatalyst. Besides, CNTs have been preferred as carriers for enzyme immobilization, because they may provide high surface area and they can easily functionalized to get the targeting properties 
for specific application. Laccase is most widely distributed in a wide range of higher plants, fungi and bacteria [44]. It's secreted out in the medium extracellularly by several fungi during the secondary metabolism but not all fungal species produce laccase [45]. It belongs to the family of the blue multi-copper oxidase, which catalyze the one electron oxidation of four reducing-substrate molecules concomitant with the four-electron reduction of molecular oxygen to water. It is also oxidative enzyme (benzendiol: oxygen oxidoreductase, EC 1.10.3.2), which has been used in various biotechnological processes. This study aims at immobilization of laccase (Aspergillus sp.) onto oxidized MWCNTs using simple mixing technique. The immobilized enzyme was characterized using FTIR, TGA, TEM and particle size distribution analysis. The stability of the immobilized enzyme at different temperatures and $\mathrm{pH}$ was also investigated relative to the free enzyme. The catalytic activity of the immobilized enzyme in the presence of silver nitrate aqueous solution was carried out after incubation for 1 and $24 \mathrm{~h}$ at room temperature in comparison with the free one.

\section{Experimental Details}

\subsection{Materials and Methods}

\subsubsection{Materials}

Multi-walled carbon nanotubes (MWCNTs), carbon 95\%, O.D L 6-9 nm $5 \mu \mathrm{m}$, pure commercial laccase from Aspergillus sp. and 2,2'-azino-bis(3ethylbenzothiazoline-6-sulphonic acid (ABTS) substrate for laccase assay were obtained by Sigma-Aldrich. All other chemicals and reagents are used without further purification.

\subsubsection{Purification and oxidation of MWCNTs}

Pristine MWCNTs $(3.0 \mathrm{~g})$ was dispersed in mixed concentrated sulphuric and nitric acids $(3: 1, \mathrm{v} / \mathrm{v})$ at ratio of $50 \mathrm{~mL}$ acid mixture per $10 \mathrm{mg}$ of MWCNTs [46] and then refluxed at $110^{\circ} \mathrm{C}$ with continuous stirring to produce oxidized carbon nanotubes (MWCNTs$\mathrm{COOH}$ ). The mixture was washed with ultrapure water until the filtrate is neutral $(\mathrm{pH} 7.0)$. The collected material was resuspended and centrifuged at $8000 \mathrm{rpm}$ for $10 \mathrm{~min}$. Finally, the obtained solid powder was dried in a vacuum oven at $70^{\circ} \mathrm{C}$ for $12 \mathrm{~h}$ and kept for further investigation.

\subsubsection{Enzyme immobilization}

The commercial laccase $(12 \mathrm{mg} / \mathrm{mL}, 75 \mathrm{U} / \mathrm{mL}$ ) was added to $10 \mathrm{mg} / \mathrm{mL}$ of oxidized MWCNTs and then ultrasonicated for $1 \mathrm{~h}$. The resulting mixture was incubated at $40^{\circ} \mathrm{C}$ with a shaking speed of $170 \mathrm{rpm}$ for $1 \mathrm{~h}$ to reach the equilibrium state. After that the immobilized laccase was separated using cooling centrifugation (Sigma, $6000 \mathrm{rpm}$ for $5 \mathrm{~min}$ ), washed with HEPES buffer, freeze-dried and stored at $-4^{\circ} \mathrm{C}$ for further analysis.

\subsubsection{Enzymatic activity assay}

The quantitative analysis of enzyme activity was determined after incubating $1.8 \mathrm{~mL}$ of the $3 \mathrm{mM}$ ABTS solution (2,2'-azino-bis (3-ethylbenzothiazoline-6sulphonic acid) prepared in a $0.2 \mathrm{M}$ acetate buffer solution (ABS, $\mathrm{pH} 4.0$ ) with $0.2 \mathrm{~mL}$ of the free enzyme mixture at $25^{\circ} \mathrm{C}$ for about $5 \mathrm{~min}$. The absorbance was examined spectrophotometrically at $420 \mathrm{~nm}$. On the other hand, $20 \mathrm{mg}$ of the prepared hybrid material (immobilized laccase onto ox-MWCNTs), $1.3 \mathrm{~mL}$ of a sodium acetate buffer $(0.2 \mathrm{M}, \mathrm{pH} 4.0)$ and $0.7 \mathrm{~mL}$ of ABTS (3 mM) were mixed and incubated for $5 \mathrm{~min}$. After that the sample was filtered and the absorbance was determined at $420 \mathrm{~nm}$. Relative activities were adapted as the percentage of the initial activity fixed as $100 \%$. All experiments were performed three times separately [47].

\subsection{Characterization}

\subsubsection{Physico-chemical characterization}

The samples were examined using PerkinElmer (FTIR) spectroscopy under certain condition such as: scan resolution: $4 \mathrm{~cm}^{-1}$, scan rate: $2 \mathrm{~mm} \mathrm{sec}^{-1}$, range: $600-4000 \mathrm{~cm}^{-1}$ and mode: transmission. The TGA was carried out on Perkin-Elmer thermogravimetric analyzer TGA 7: The dry samples were heated from room temperature to $400^{\circ} \mathrm{C}$ at $5^{\circ} \mathrm{C} / \mathrm{min}$. The morphologies and the particle size were carried out with a JEOL transmission electron microscope (TEM) and the particle size and zeta potential were carried out using DLS Malvern instrument.

\subsubsection{Biochemical characterization of the} immobilized and free laccase

The influence of $\mathrm{pH}$ values on laccase activity was investigated. The immobilized and free laccases were incubated separately for $60 \mathrm{~min}$ for each sample in various buffers with pHs ranging from 3.0 to 8.0 at $40^{\circ} \mathrm{C}$ and $3 \mathrm{mM}$ ABTS as the substrate. Also, the influence of temperature on laccase activity was carried out. The immobilized and free laccases were incubated for $60 \mathrm{~min}$ at temperatures ranging from 30 to $70^{\circ} \mathrm{C}$ using a buffer with $\mathrm{pH} 3.0$ and $3.0 \mathrm{mM} \mathrm{ABTS}$ as the 
substrate, then, the remaining activities were determined at $25^{\circ} \mathrm{C}$ after cooling.

The thermal stability at 50 and $70^{\circ} \mathrm{C}$ against laccase activities was also determined as follows: the immobilized and free laccases were incubated at temperatures 50 and $70^{\circ} \mathrm{C}$ using a buffer with $\mathrm{pH} 3.0$ for $60 \mathrm{~min}$. The remaining activities were determined at $25^{\circ} \mathrm{C}$. Aliquots of samples of $3 \mathrm{~mL}$ were taken at each time interval $(0,15,30,45$ and $60 \mathrm{~min})$, filtered and used for the examination. The reading was repeated three times. The laccase activity was fixed as $100 \%$ at the optimum $\mathrm{pH}$ or temperature.

\section{Results and Discussion}

\subsection{Physico-chemical characterization}

Figure 1 shows FTIR spectra of the immobilized laccase in comparison with the carrier (ox-MWCNTs). In the case of the ox-MWCNTs spectrum, the characteristic peaks at 2926, 2856, 1741, 1563, 1404, and $1381 \mathrm{~cm}^{-1}$ were assigned to $-\mathrm{CH}_{2}$ (str), $-\mathrm{CH}-$ (str), $\mathrm{C}=\mathrm{O}$ (str), -C-C- (str), $-\mathrm{OH}$ (bending) and $-\mathrm{C}-\mathrm{O}$ (str) groups, respectively, which are attributed to the vibrations of the carbon skeleton after oxidation process [48]. On the other hand, in the case of the immobilized enzyme spectrum, not all the characteristic peaks belonging to the ox-MWCNTs appeared in the spectrum. However, the strong peak was appeared at $3432 \mathrm{~cm}^{-1}$ which is assigning to $-\mathrm{NH}_{2}$ groups of the protein enzyme. This may be due to the completely adsorption of the enzyme by the carrier through the physico-chemical interactions.

Figure 2 and Table 1 show TGA diagrams and weight loss (\%) data at temperature range $30-1000^{\circ} \mathrm{C}$ of the immobilized enzyme in comparison with the carrier (ox-MWCNTs). It can be noticed that OxMWCNTs exhibited high thermal stability (weight loss about $9.6 \%$ at $\left.>455^{\circ} \mathrm{C}\right)$.

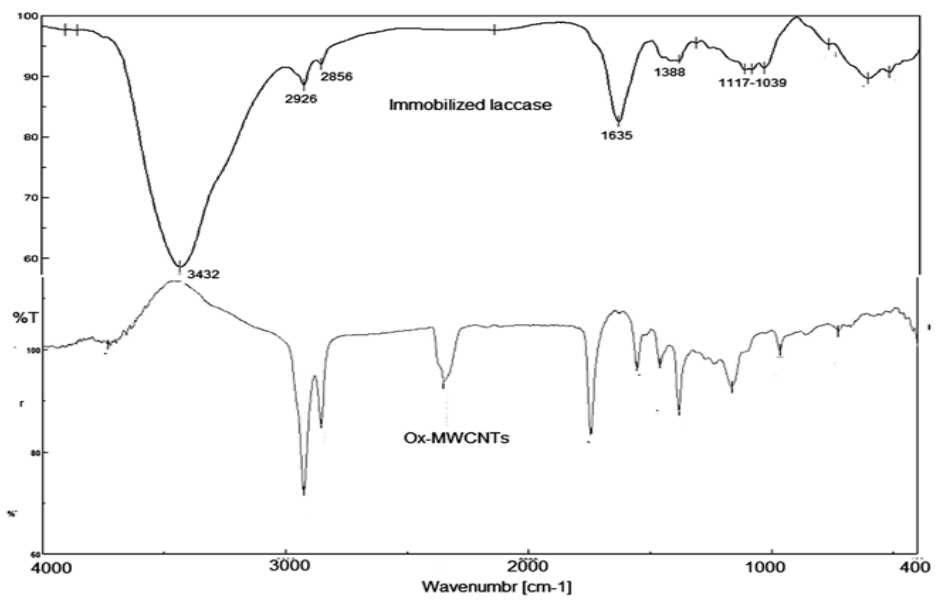

Figure 1. FTIR spectra of the immobilized laccase in comparison with the carrier (ox-MWCNTs).

Table 1. TGA data of the prepared materials

\begin{tabular}{|l|l|l|l|l|}
\hline \multirow{2}{*}{ Sample } & \multicolumn{4}{|c|}{ Wight loss (\%) at different temperatures $\left({ }^{\circ} \mathrm{C}\right)$} \\
\cline { 2 - 5 } & $40-120$ & $120-281$ & $281-350$ & $350-780$ \\
\hline Ox-MWCNTs & 12 & ----- & ---- & 9.6 \\
\hline $\begin{array}{l}\text { Immobilized } \\
\text { laccase }\end{array}$ & 15 & 13 & ----- & 72 \\
\hline
\end{tabular}

Table 2. Particle size distribution and zeta potential analysis using DLS technique

\begin{tabular}{|c|c|c|}
\hline Sample & Particle size $(\mathrm{nm})$ & Zeta potential $(\mathrm{mv})$ \\
\hline Ox-MWCNTs & $180 \pm 22.7$ & $-12.2 \pm 7.2$ \\
\hline Immobilized laccase & $396 \pm 17.9$ & $-5.6 \pm 3.4$ \\
\hline
\end{tabular}




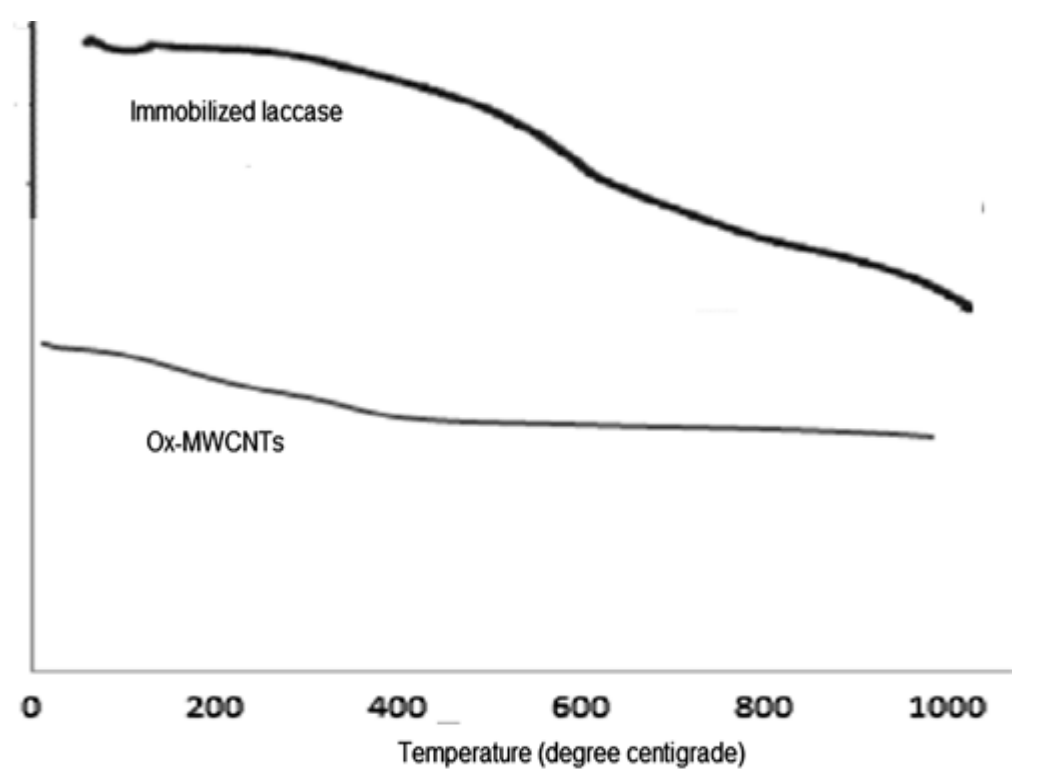

Figure 2. TGA diagrams of the immobilized laccase in comparison with the carrier (ox-MWCNTs).
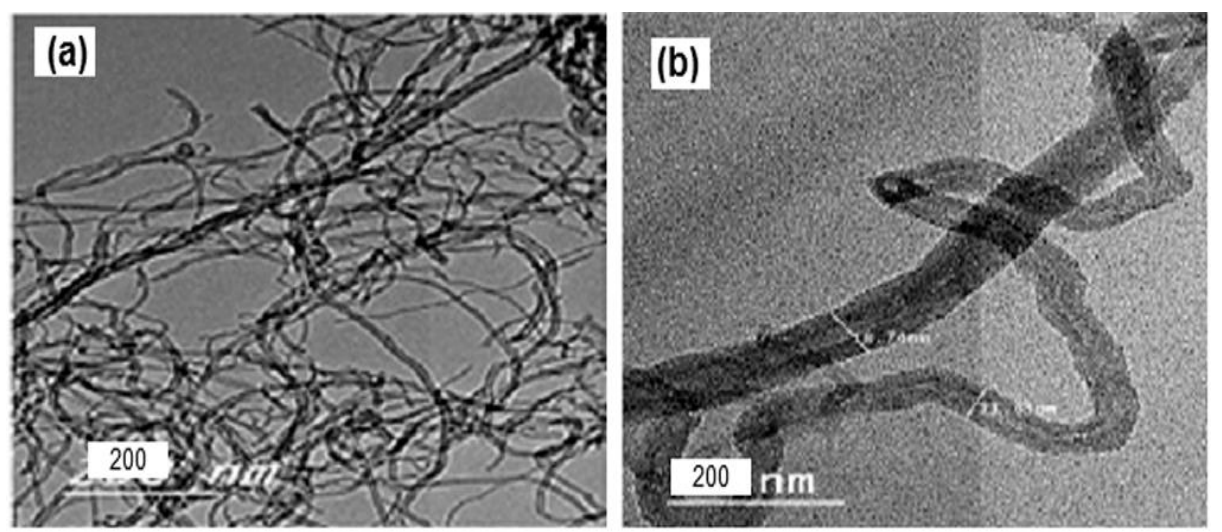

Figure 3. TEM images of (a) the carrier (ox-MWCNTs) and (b) the immobilized laccase at scale bar $200 \mathrm{~nm}$.

After enzyme immobilization, it had three decomposition steps. The first starts at $40-120^{\circ} \mathrm{C}$, the second at $120-281^{\circ} \mathrm{C}$ and the third one over $350^{\circ} \mathrm{C}$ with weight loss about 15,13 and $72 \%$, respectively. This may be due to the loss of the unbound water and the presence of enzyme molecules. Moreover, these results proved that the successful laccase immobilization onto oxidized MWCNTs was taken place via covalent bonds.

Figure 3 shows TEM images of the immobilized enzyme in comparison with the carrier (ox-MWCNTs). It can be noticed that the diameters of the immobilized laccase were increased relative to that in case of the oxidized MWCNTs suggesting that adsorption of the laccase enzyme particles occurred in the matrices. This observation was confirmed by the particle size distribution analysis (Figure 4). Table 2 shows the particle size distribution analysis of the immobilized laccase onto MWCNTs in comparison with the carrier (ox-MWCNTs). The particle size of the carrier was increased from 180 to $396 \mathrm{~nm}$ after laccase immobilization. On the other hand, the ox-MWCNTs had high negative zeta potential value about $-12 \mathrm{mv}$. While, after enzyme immobilization, it was about -5.6 $\mathrm{mv}$. This may be due to the high tendency to flocculate and the presence of the attractive forces between the different charges (Table 2).

\subsection{Biocatalytic activity evaluation}

The silver nitrate solution with no laccase enzyme was used as the control, which showed no colour change during the incubation under the same conditions. While, after $1 \mathrm{~h}$ of incubation, the silver nitrate solution had slight colour intensity change in the case of laccase enzyme before and after immobilization, On the other hand, after $24 \mathrm{~h}$ of incubation, high colour changes could be obtained this may be due to the catalytic effect of the released enzyme from the carrier (ox-MWCNTs). The particle size of the $\mathrm{AgNO}_{3}$ after $1 \mathrm{~h}$ of incubation with the immobilized laccase was around of $295 \pm 70.7$ and $95 \pm 25.1 \mathrm{~nm}$ with PDI about 0.52 . 

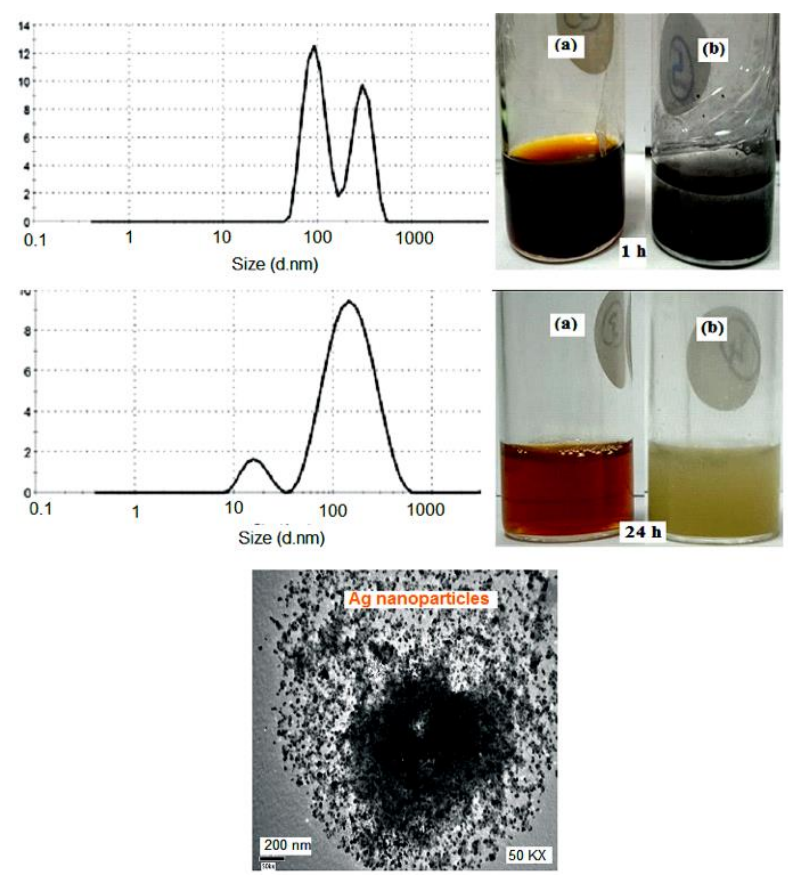

Figure 4. Particle size distribution analysis at room temperature using DLS technique and Photographs of the treated $\mathrm{AgNO}_{3}$ with laccase (a) before and (b) after immobilization onto ox-MWCNTs after incubation for 1 and $24 \mathrm{~h}$ at room temperature in aqueous media.

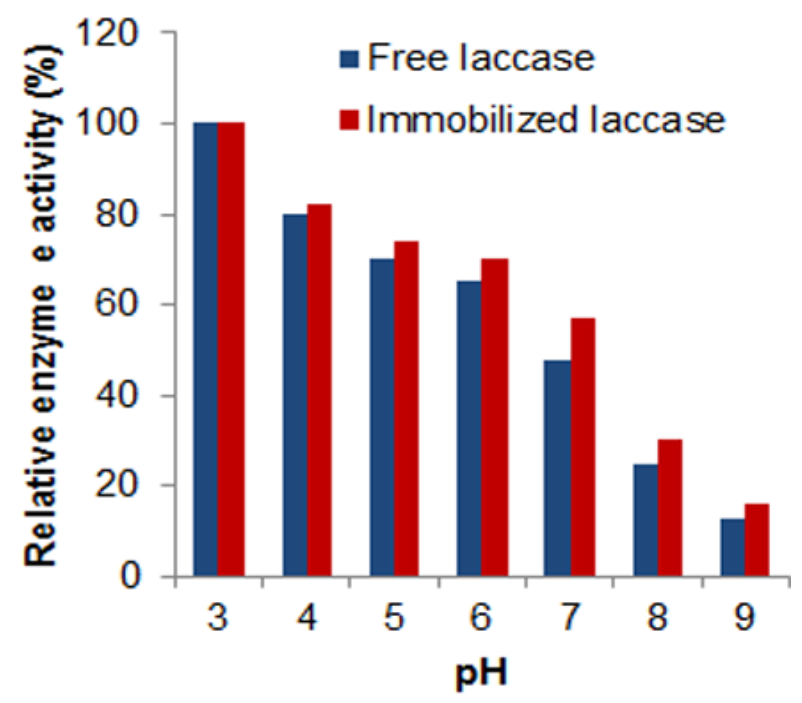

Figure 5. Effect of pH on stability of free and immobilized laccase onto ox-MWCNTs.

While, after $24 \mathrm{~h}$ of incubation, the size was around of $165 \pm 87.2$ and $17 \pm 4.4 \mathrm{~nm}$ with PDI about 0.46 . In other words, the first peaks (295 and $165 \mathrm{~nm}$ ) may be assigned to the ox-MWCNTs dissociation particles, while, the other ones belong to the silver nanoparticles (95 and $17 \mathrm{~nm}$ ).

\subsection{Biochemical characterization}

\subsubsection{Effect of $\mathrm{pH}$ value on laccase activity}

The optimum $\mathrm{pH}$ for laccases depends on the substrate and on its redox potential. Fungal laccases are usually stable at acidic $\mathrm{pH}$, although $\mathrm{pH}$ stability varies considerably depending on the source of the enzyme [49]. In the present study, the influence of $\mathrm{pH}$ on the laccase activity was examined over a $\mathrm{pH}$ range from 3 to 8 , as shown in Figure 5. It was observed that the optimum activity was recorded at $\mathrm{pH} 3$ for both the free and immobilized laccase, with high activity level $(100 \%)$. Besides, the free laccase had low activity in all $\mathrm{pH}$ range relative to the immobilized one, which proves that the immobilized laccase is relatively stable at different $\mathrm{pH}$ values. Moreover, at acidic $\mathrm{pH}$ range $(4,5$ and 6), the immobilized enzyme retained 82,74 and 70 $\%$ relative activity in comparison with that in the case of the free one $(80,70$ and $65 \%$, respectively). 

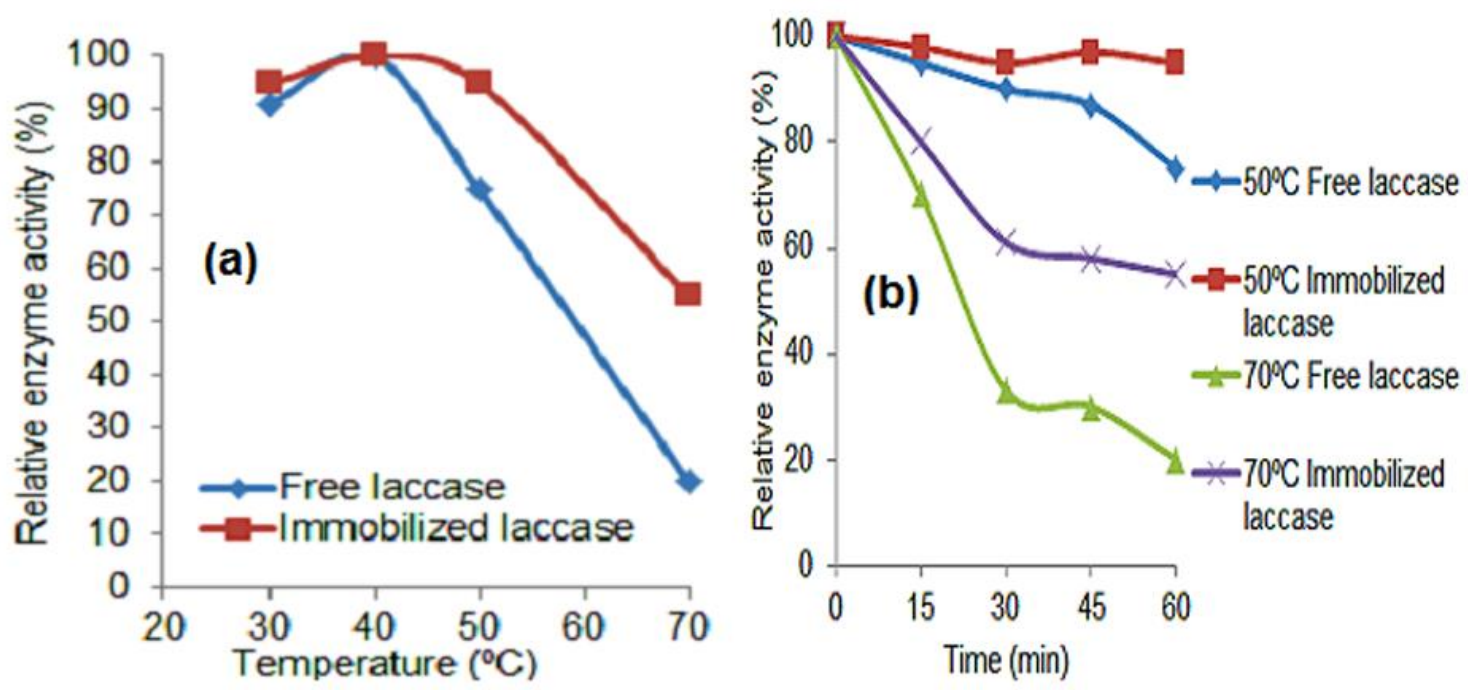

Figure 6. Effect of (a) temperature and (b) thermal stability at 50 and $70^{\circ} \mathrm{C}$ on the activity of free and immobilized laccase.

Zofair [50] and Daronch et al. [51] reported recently that the maximum activity for both free and immobilized laccase was at $\mathrm{pH}$ 3. Patrick et al. [52] stated that the $\mathrm{pH}$ profile is the result of two opposing effects: the first effect is due to the redox potential difference between a reducing substrate (phenolic compound) and the Type 1 copper center of laccase, where the electron transfer rate is favored for phenolic substrates at a high $\mathrm{pH}$; the second effect is generated by the binding of a hydroxyl anion to the type 2/type 3 copper centers of laccase, which inhibits the binding of oxygen, the terminal electron acceptor. Therefore, the activity at alkaline $\mathrm{pH}$ could be inhibited because of the increased amount of hydroxyl ions [53].

\subsubsection{Effect of temperature and thermal stability on laccase activity}

The effect of temperature on the laccase activity before and after immobilization was carried out, as illustrated in Figure 6a. It was noticed that when the temperature was increased, the activity of both enzymes increase till $40^{\circ} \mathrm{C}$, accompanying a slightly higher activity for the immobilized one relative to the free form. On the other hand, with a further increase in temperature up to $70^{\circ} \mathrm{C}$, the activity was decreased in the case of both enzymes. The optimal temperature was $40 \stackrel{\circ}{\circ}$. Besides, the immobilized laccase onto oxMWCNTs is more stable at a high temperature relative to the free one. At $70{ }^{\circ} \mathrm{C}$, the immobilized laccase retained $55 \%$ of its relative activity in comparison with that in the case of the free form $(20 \%)$ under the same condition. These results are in agreement with the previous data [54] which reported that in spite of an increasing in the temperature enhances the conjugation between the laccase and the carrier, the enzyme activity can be stimulated. But, a further temperature increase result in the loss of enzyme activity because of the enzyme denaturation [55]. The improvement in the thermal stability of the immobilized laccase onto oxMWCNTs may be caused by a strong enzyme-carrier interaction between the carboxylic acid groups at MWCNTs and the enzyme protein reaction, which enhances the stability at high temperature. Also, the molecular motions of enzyme could be protected, which may result in the improvement in the protein structure rigidity. Thermal stability is one of the most important parameters for enzyme applications in the industrial sectors. In this work, the thermal stability of the immobilized laccase onto ox-MWCNTs compared to the free form was investigated (Figure 6b). This was done by incubating the immobilized and free enzyme in a buffer $(\mathrm{pH} 3)$ at different temperatures $\left(50\right.$ and $\left.70^{\circ} \mathrm{C}\right)$ for $1 \mathrm{~h}$. After that the activities were determined as shown in Fig $6 \mathrm{~b}$. It was observed that when the temperature was increased up to $70^{\circ} \mathrm{C}$, the free enzyme loses up to $80 \%$ of its activity, whereas the immobilized enzyme retains $45 \%$ of its relative activity under the same conditions. The inhibition in the free enzyme activity at a high temperature has also been previously reported [56]. Based on these results, laccase immobilization onto ox-MWCNTs improved the thermal stability of the immobilized enzyme relative to the free one.

\section{Conclusion}

Oxidized MWCNT can be utilized efficiently as a carrier for Aspergillus sp. laccase immobilization using simple mixing technique via ultrasonic treatment. FTIR, TGA and TEM confirmed the attachment of laccase to the ox-MWCNTs surface. Moreover, the prepared biohybrid material was successfully used for the treatment of silver nitrate aqueous solution to 
produce the Ag nanoparticles. This biocatalytic activity exhibiting similar efficiency when using the free enzyme. Also, the immobilized enzyme results in an enhancement in the activity and thermal stability at a moderate temperature relative to that in the case of the free form. Overall, the results proved the immobilization reaction and the biocatalytic performance of laccase onto ox-MWCNTs as a bionanotechnological trend in all the industrial field of its utilization.

\section{References}

[1] TA Hilder, JM. Hill, Theoretical comparison of nanotube materials for drug delivery, IET Digital Library, 3 (2008) 18-24. [DOl]

[2] A.A. Haroun, H.A.A. Taie, Cytotoxicity and antioxidant activity of beta vulgaris extract released from grafted carbon nanotubes-based nanocomposites, Macromolecular Symposia, 337 (2014) 25-33. [DOl]

[3] E. Khaled, MS. Kamel, HNA. Hassan, A.A. Haroun, AM. Youssef, Hassan, Y. Aboul-Enein, Novel multi walled carbon nanotubes/ $\beta$ cyclodextrin based carbon paste electrode for flow injection potentiometric determination of piroxicam, Talanta, 97 (2012) 96-102. [DOl]

[4] S. Prakash, M. Malhotra, W. Shao, C. TomaroDuchesneau, S. Abbasi, Polymeric nanohybrids and functionalized carbon nanotubes as drug delivery carriers for cancer therapy, Advanced Drug Delivery Reviews, 63 (2011) 1340-1351. [DOl]

[5] C.G. Silva, A.P.M. Tavares, G. Dražić, A.M.T. Silva, J.M. Loureiro, J.L. Faria, Controlling the surface chemistry of multiwalled carbon nanotubes for the production of highly efficient and stable laccase-based biocatalysts, Chem Plus Chem, 79 (2014) 1116-1122. [DOI]

[6] Y. Amano, A. Koto, S. Matsuzaki, H. Sakamoto, T. Satomura, S.I. Suye, Construction of a biointerface on a carbon nanotube surface for efficient electron transfer, Materials Letters, 174 (2016) 184-187. [DOI]

[7] Y. Fan, G. Wu, F. Su, K. Li, L. Xu, X. Han, Y. Yan, Lipase oriented-immobilized on dendrimer-coated magnetic multi-walled carbon nanotubes toward catalyzing biodiesel production from waste vegetable oil, Fuel, 178 (2016) 172-178. [DOl]

[8] S. Gupta, C.R. Prabha, C.N. Murthy, Functionalized multi-walled carbon nanotubes/ polyvinyl alcohol membrane coated glassy carbon electrode for efficient enzyme immobilization and glucose sensing, Journal of environmental chemical engineering, 4 (2016) 3734-3740. [DOI]

[9] C. Ji, J. Hou, V. Chen, Cross-linked carbon nanotubes-based biocatalytic membranes for micro-pollutants degradation: performance, stability, and regeneration, Journal of Membrane Science, 520 (2016) 869-880. [DOl]

[10] A.A. Haroun, H.A. Taie, Preparation and rational biological evaluation of functionalized carbon nanotube with plant extracts. Proceeding at $2^{\text {nd }}$ Int. Symposium on Materials and Sustainable Development, 9-10 November, Algeria, (2015).

[11] A.A. Haroun, F. Ayoob, E. Nashy, O. Mohamed, A. Rabi, Sol-gel preparation and in vitro kinetic release study of albendazoleimmobilized MWCNTs, Egyptian Journal of Chemistry, 62 (2019) 645 - 654. [DOI]

[12] F. Ayoob, A.A. Haroun, E. Nashy, O. Mohamed, S. Abdelshafy, A. Rabi, Preparation, characterization and in vitro toxicity study of antiparasitic drugs loaded onto functionalized MWCNTs, Egyptian Journal of Chemistry, 63 (2020) 3829-3836. [DOl]

[13] A.A.Haroun, H.A. Amin, S.H. Abd El-Alim, Preparation, characterization and In vitro biological activity of soyasapogenol B loaded onto functionalized multi-walled carbon nanotubes, Current Bioactive Compounds, 14 (2018) 364-372. [DOI]

[14] A.A. Haroun, H.A. Amin, S.H. Abd El-Alim, Imobilization and in vitro evaluation of soyasapogenol B onto functionalized multiwalled carbon nanotubes, IRBM 39 (2018) 3542. [DOI]

[15] A.A. Haroun, A.M. Elnahrawy, H.I. Abd-Alla, Sol-gel preparation and in vitro cytotoxic activity of nanohybrid structures based on multi-walled carbon nanotubes and silicate, Inorganic and Nano-Metal Chemistry, 47 (2017) 1023-1027. [DOI]

[16] A.A. Haroun, B.M. Zaki, M. Shalash, R.A. Morsy, Preparation and Histological Study of Multi-Walled Carbon Nanotubes Bone Graft in Management of Class II Furcation Defects in Dogs, Open Access Macedonian Journal of Medical Sciences, 7 (2019) 3634-3641. [DOI] 
[17] A.A. Haroun, A.H. Mossa, S.M. Mohafrash, Preparation and biochemical evaluation of functionalized multi-walled carbon nanotubes with P. granatum extract, Current Bioactive Compounds, 5 (2019) 138-144. [DOl]

[18] A.A. Haroun, Carbon Nanotubes as Innovative Materials for Bone Grafting Applications, Crimson PublishersWings to the Research, 2 (2019) 1-3. [DOI]

[19] H.A. Amin, A.A. Haroun, Comparative studies of free and immobilized Aspergillus flavus onto functionalized multiwalled carbon nanotubes for soyasapogenol B production, Egyptian Pharmaceutical Journal, 16 (2017) 138-143. [DOI]

[20] A.A. Haroun, E.F. Ahmed, M. Esawy, Immobilization and characterization of levansucrase enzyme onto functionalized multiwalled carbon nanotubes, Egyptian Journal of Chemistry, 61 (2018) 667-678. [DOl]

[21] AA. Haroun, HM. Ahmed, EF. Ahmed, (2019) Functionalized multi-walled carbon nanotubes as emerging carrier for biological applications, Proceedings of the 5th World Congress on New Technologies, [DOI]

[22] A.A. Haroun, H.M. Ahmed, A.H. Mossa, S.M. Mohafrash, E.F. Ahmed, Production, characterization and immobilization of Aspergillus versicolor L-asparaginase onto multi-walled carbon nanotubes, Biointerface Research in Applied Chemistry, 10 (2020) 5733-740. [DOI]

[23] AM. Abdel Naby, MA. Hashem, MA. Esawy, Immobilisation of Bacillus subtilis œamylase.and characterization of its enzyme properties, Microbiological Research, 153 (1998) 319-325. [DOI]

[24] A.L Cordeiro, T. Lenk, C. Werner, Immobilization of Bacillus licheniformis $\alpha$ amylase onto reactive polymer films, Journal of Biotechnology, 154 (2011) 216-221. [DOI]

[25] EA. Karam, WAA. Wahab, SAA. Saleh, ME. Hassan, AL. Kansoh, MA. Esawy, Production, immobilization and thermodynamic studies of free and immobilized Aspergillus awamori amylase, International Journal of Biological Macromolecules, 102 (2017) 694-703. [DOI]

[26] H. Bisswanger, Enzyme assays review, Perspectives in Science, 1 (2014) 41-55. [DOI]

S. Sadeghzadeha, Z.G. Nejadb, S. Ghasemic, M. Khafajid, S.M. Borghei, Removal of bisphenol $A$ in aqueous solution using magnetic crosslinked laccase aggregates from Trametes hirsute, Bioresource Technology, 306 (2020) 123-169. [DOI]

[28] M. Masjoudi, M. Golgoli, Z.G. Nejad, S. Sadeghzadeh, S.M. Borghei, Pharmaceuticals removal by immobilized laccase on polyvinylidene fluoride nanocomposite with multi-walled carbon nanotubes, Chemosphere, 263 (2021) 128043. [DOI]

[29] K.S. Muthuvelu, R. Rajarathinama, R.N. Selvaraj, V.B. Rajendren, A novel method for improving laccase activity by immobilization onto copper ferrite nanoparticles for lignin degradation, International Journal of Biological Macromolecules, 152 (2020) 1098-1107. [DOI]

[30] X. Chen, B. He, M. Feng, D. Zhao, J. Sun, Immobilized laccase on magnetic nanoparticles for enhanced lignin model compounds degradation, Chinese Journal of Chemical Engineering, 28 (2020) 2152-2159. [DOI]

[31] X. Qiua, S. Wanga, S. Miaoa, H. Suob, H. Xua, Y. Hu, Co-immobilization of laccase and ABTS onto amino-functionalized ionic liquid-modified magnetic chitosan nanoparticles for pollutants removal, Journal of Hazardous Materials, 401 (2021) 123353. [DOI]

[32] C. Zhang, S. You, Y. Liu, C. Wang, Q. Yan, W. Qi, R. Su, Z. He, Construction of luffa spongebased magnetic carbon nanocarriers for laccase immobilization and its application in the removal of bisphenol $A$, Bioresource Technology, 305 (2020) 123085. [DOI]

[33] M. Bilal, Z. Jing, Y. Zhao, H.M.N. Iqbal, Immobilization of fungal laccase on glutaraldehyde crosslinked chitosan beads and its bio-catalytic potential to degrade bisphenol A, Biocatalysis and Agricultural Biotechnology, 19 (2019) 101174. [DOI]

[34] C. Zhang, S. You, J. Zhang, W. Qi, R. Su, Z. $\mathrm{He}$, An effective in-situ method for laccase immobilization: Excellent activity, effective antibiotic removal rate and low potential ecological risk for degradation products, Bioresource Technology, 308 (2020) 123271. [DOI]

[35] J. Liu, X. Shen, Z. Zheng, M. Li, X. Zhuc, H. Cao, C. Cui, Immobilization of laccase by $3 \mathrm{D}$ bioprinting and its application in the biodegradation of phenolic compounds, International Journal of Biological Macromolecules, 164 (2020) 518-525. [DOI] 
[36] D. Wang, J. Lou, J. Yuan, J. Xu, R. Zhu, Q. Wang, $X$. Fan, Laccase immobilization on coreshell magnetic metal-organic framework microspheres for alkylphenol ethoxylate compound removal, Journal of Environmental Chemical Engineering, 9 (2021) 105000. [DOI]

[37] W. Zhoua, W. Zhanga, Y. Cai, Laccase immobilization for water purification: A comprehensive review, Chemical Engineering Journal, 403 (2021) 126272. [DOl]

[38] P. Cao, H. Liu, D. Wu, X. Wang, Immobilization of laccase on phase-change microcapsules as self-thermoregulatory enzyme carrier for biocatalytic enhancement, Chemical Engineering Journal, 405 (2021) 126695. [DOl]

[39] Z. Lia, Z. Chena, Q. Zhua, J. Songa, S. Lia, X. Liu, Improved performance of immobilized laccase on Fe3O4@C-Cu2+ nanoparticles and its application for biodegradation of dyes, Journal of Hazardous Materials, 399 (2020) 123088. [DOI]

[40] M. Primo, G. Kravanja, Z. Knez, A. Crnjac, M. Leitgeb, Immobilized laccase in the form of (magnetic) cross-linked enzyme aggregates for sustainable diclofenac (bio) degradation, Journal of Cleaner Production, 275 (2020) 124121. [DOI]

[41] H. Yamaguchi, M. Miyazaki, Laccase aggregates via poly-lysine-supported immobilization onto PEGA resin, with efficient activity and high operational stability and can be used to degrade endocrine-disrupting chemicals, Catalysis Science and Technology, 11 (2020) 934-942. [DOI]

[42] Y. Zhang, M. Piao, L. He, L. Yao, T. Piao, Z. Liua, Y. Piao, Immobilization of laccase on magnetically separable biochar for highly efficient removal of bisphenol A in water, RSC Advances, 10 (2020) 4795-4804. [DOI]

[43] W. Feng, P. Ji, Enzymes immobilized on carbon nanotubes, Biotechnology Advances, 29 (2011) 889-895. [DOI]

[44] G. Diamantidis, A. Effosse, P. Potier, R. Bally, Purification and characterization of the first bacterial laccase in rhizopheric bacteria Azospirillium lipoferum, Soil Biology and Biochemistry, s32 (2000) 919-927. [DOI]

[45] O.V. Morozova, G.P. Shumakovich, M.A. Gorbacheva, S.V. Shleev, A.I.Yaropolov, Blue laccases, Biochemistry, 72 (2007) 1136-1150. [DOI]
[46] M.W. Marshall, S. Popa-Nita, J.G. Shapter, Measurement of functionalized carbon nanotubes carboxylic acid groups using a simple chemical process, Carbon, 44 (2006) 1137-1141. [DOI]

[47] P. habimana, J. Gao, J.P. Mwizerwa, J.B. Ndayambaje, H. Liu, P. Luan, L. Ma, Y. Jiang, Improvement of laccase activity via covalent immobilization over mesoporous silica coated magnetic multiwalled carbon nanotubes for the discoloration of synthetic dyes, ACS Omega 6 (2021) 2777-2789. [DOI]

[48] H.J. Lee, S.J. Oh, J.Y. Choi, J. Kim, L.S. Han, J.B. Back, In situ synthesis of poly(ethylene terephthalate) (PET) in ethylene glycol containing terephthalic acid and functionalized multiwalled carbon nanotubes (MWNTs) as an approach to MWNT/PET nanocomposites, Chemistry of Materials, 17 (2005) 5057-5064. [DOI]

[49] P. Baldrian, Fungal laccases - occurrence and properties, FEMS Microbiology Reviews, 30 (2006) 215-245. [DOI]

[50] S.F. Zofair, A. Arsalan, M.A. Khan, F.A. Alhumaydhi, H. Younus, Immobilization of laccase on sepharose-liked antibody support for decolourization of phenol red, International Journal of Biological Macromolecules, 161 (2020) 78-87. [DOI]

[51] N.A. Daronch, M. Kelbert, C.S. Pereira, D. de Olivera, Elucidating the choice of precise matrix for laccase immobilization, A Review, Chemical Engineering Journal, 397 (2020) 12506. [DOI]

[52] F. Patrick, G. Mtui, A. M. Mshandete, G. Johansson, A. Kivaisi, Purification and characterization of a laccase from the basidiomycete Funalia trogii (Berk.) isolated in Tanzania, African Journal of Biochemistry Research, 3 (2009) 250-258.

[53] A. Daâssi, A. Prieto, H. Zouari-Mechichi, M. J. Martínez, M. Nasri, T. Mechichi, Degradation of bisphenol $A$ by different fungal laccases and identification of its degradation products, International Biodeterioration \& Biodegradation, 110 (2016) 181-188. [DOI]

[54] D. Tuncay, H. Yagar, Decolorization of reactive blue-19 textile dye by Boletus edulis laccase immobilized onto rice husks, International Journal of Environmental Science and Technology, 17 (2020) 3177-3188. [DOI] 
[55] K.S. Muthuvelu, R. rajarathinam, R.N. Searaj, V.B.A. Rajendren, A novel method for improving laccase activity by immobilization onto copper ferrite nanoparticles for linin degradation, International Journal of Biological Macromolecules, 152 (2020) 1098-1107. [DOI]

[56] S. Rouhani, S. Azizi, R.W. Kibechu, B.B. Mamba, T.A.M. Msagati, Laccase immobilized $\mathrm{Fe}_{3} \mathrm{O}_{4}$-grahene oxide nano-biocatalyst improve stability and immobilization efficiency in the green preparation of sulfa drugs, Catalysts, 10 (2020) 1-15. [DOI]

\section{Acknowledgement}

The authors are thankful to National Research Centre, Giza, Egypt for supporting this work.

\section{Funding}

No funding was received for conducting this study.

\section{Conflict of interest}

The authors have no conflicts of interest to declare that they are relevant to the content of this article.

\section{Does this article screened for similarity?}

Yes

\section{About the License}

(C) The author(s) 2021. The text of this article is open access and licensed under a Creative Commons Attribution 4.0 International License 